\title{
Collective Amnesia of the Jewish Romania Narratives Holocaust in Identities \\ and \\ of \\ Current National
}

Alexandru Cuc, M.A. ${ }^{1}$

This article represents a summary of a recent grant proposal submitted to the Romanian Government. The proposal deals with the intergenerational basis of collective amnesia about the Romanian Holocaust and its effects on the current narratives of national identity in Romania. In 1930, Romania was home to seven hundred fifty thousand Jews. By the end of World War II two hundred fifty thousands Jews and nineteen thousands Gypsies are estimated to have been murdered under Romanian jurisdiction (Butnaru, 1992; loanid, 2000). The widespread absence of recollections about these events from Romanians' collective memory is the focus of my project.

The recent rise of democracy around the world since the fall of Communism has brought about a change in how some societies come to terms with their own traumatic past (Rosenberg, 1995). From South Africa - with its Commission on Truth and Reconciliation- to Eastern Europe - with its intro-

1: Department of Psychology, Graduate Faculty, New School University, New York, USA 
duction of the lustrace law in Czechoslovakia and the opening of the Stasi files in Eastern Germany to South America - with its Mothers of the Plaza de Mayo - nations and their citizens have developed both formal and informal means of addressing the need to reconcile past with present. In seeking a reconciliatory narrative about the past these societies hope that unearthing the 'historical truth' will create a cathartic reaction at societal level and that the disturbing events of the past will be integrated within the larger constitutive narrative of the nation (Rosenberg, 1995; Spence, 1982).

Collective amnesia, a relatively recent topic on the agenda of collective memory research, refers to a group's inability and/or unwillingness to remember certain traumatic events about its past. A social phenomenon par excellence, collective amnesia raises new and interesting questions about the generational nature of remembering and forgetting. Group forgetting may, for instance, be restricted within the members of one generation or it may spread across more generations (Mannheim, 1952; Stierlin, 1981). This proposal deals in part with some of the factors that influence the formation, persistence, and change of this differential group forgetting across generations (Cuc \& Hirst, 2001).

Two kinds of institutional responses to traumatic public events have been widely used: silence and repression. In countries where major traumatic events have taken place (e.g., China, Argentina, Bolivia, Chile, Israel, Greece, Spain) the institutional response has often been to forget and neutralize what happened. One form of institutional repression is institutional erasure, in which the location of 
a crime or traumatic event is discretely covered with new architectural artifacts or simply left unmarked (Swedenburg, 1995). The destruction of villages and ethnic neighborhoods during Ceausescu's regime, under the pretext of modernization, has probably erased any architectural traces of the Jewish communities in Romania.

In the case of Romania, the collective amnesia about the national Holocaust spans across three generations in Romania; from the end of the Second World War to the present. Some members of the First Generation, the Holocaust generation, probably witnessed the events themselves. The Second Generation may have only heard stories about the Jewish Holocaust, as by the time of their education there was no mention of it in the history textbooks or in the state-controlled media (Florian, 1994). The Third Generation, the post-Communist generation, although experiencing more access to knowledge about the past, is still being told an official version that denies the existence of a Romanian Holocaust (Shafir, 1994).

Some specific questions that the proposed research seeks to answer are: 1) What do Romanians remember about the national Holocaust of World War II? 2) What was the role of localized mnemonic practices such as family story telling and commemorations, in the preservation of these memories?

The Id: Fall 2003 - Vol. 1 


\section{Study 1}

Records of the Romanian Holocaust have been preserved in the form of governmental and media documents, personal records and testimonies (loanid, 2000). Based on these records an extensive questionnaire can be designed that would include multiple-choice questions about the Jewish and Gypsy populations and their persecutions in different regions of Romania throughout the duration of the war. For instance, for the question 'How many Jews were living in Romania in the 1930's?' participants would have to choose their answer from the following: 757,000 (the most accurate estimate from census documents of the time), $1,020,000,245,000,82,000$, and 522,000. Each of the incorrect answers will be ranked from 1 to 4 depending on their distance from the correct answer. The estimated ranks for each group (averaged across all participants) will represent the degree of amnesia for that particular group. The estimated distances in ranks across the question do not reflect, to be sure, similar degrees of distance from the truth. They are rather to be interpreted as approximations useful for data interpretation. I intend to study three different groups corresponding to the aforementioned generations. Participants' knowledge of the Second World War events in Romania will be assessed in a knowledge questionnaire prior to the administration of the memory questions about the Holocaust.

Participants' various mnemonic practices concerning traumatic events constitute a separate but no less important issue. The mnemonic practice I am

The Id: Fall 2003 - Vol. 1 
most concerned with is how people talk about Holocaust within families. The way I plan to address this issue methodologically is by having a subsample of participants spanning three family generations: grandparents, parents, and children. The mnemonic practice interview will contain questions probing family talk and activities about the past, especially of traumatic national events, (e.g., interethnic conflicts, wartime stories, etc.) Do grandparents tell stories about their personal experiences with the Second World War and, if so, how often? Are there favorite stories that are told repeatedly at family get-togethers? Does the family talk openly about issues like anti-Semitism in Romania, etc.? In this study I also expect to find an inverse relation between the degree of amnesia and the complexity of mnemonic practices within a family: the more a family talks about traumatic events of the past the less likely that its members will be prone to forget about these events.

\section{Study 2}

The second question addressed in this proposal concerns the relation between one's sense of national identity in the context of changing interpretations about traumatic historical events (Feldman, 2001). As Hobsbawm (1972) wrote: "To be a member of any human community is to situate oneself with regard to its past, if only by rejecting it," (p. 5). In other words, as younger generations grow more distant in time from the actual historical events are they more susceptible to the official story told about these events if no competing story is available?

Using a detailed interview on national identity nar-

The Id: Fall 2003 - Vol. 1 
ratives developed by Carol Feldman (2001) at New York University, I propose the study of three different generations of Romanians. The interview will ask general questions such as: "Please describe what it means to you to be a Romanian [...] I am interested in how you think of yourself and what gives you a sense of identity. Please try to give some examples that would make me understand it [...]" In addition there will be some specific questions pertaining directly to the Jewish Holocaust problem such as: "Do you know anything about the genocide of the Jewish population in Romania during Second World War? [...] If this statement were true how would that affect your notion of what if means to be a Romanian today? [...] "

A relevant comparison for the purpose of this research is that between Romanians who could have been eye-witnesses to the events and those who could not (by simple geographical location). This will allow me to construct a complete picture of the historical landscape of Holocaust understanding in Romania. Moreover, a comparison of their children and grandchildren's answers will be equally relevant to the extent that it will provide information on the transmission of historical knowledge across generations.

\section{References}

Butnaru, I.C. (1992). The Silent Holocaust: Romania and its Jews. NY: Greenwood Press.

Cuc, A., \& Hirst, W. (2001). Implicit theories and context in personal recollection: Romanians' 
recall of their political and economic past. Applied Cognitive Psychology, 15, 45-60

Feldman, C.F. (2001). Narratives of national identities as group narratives. In Jens Brockmeier \& Donal Carbaugh (Eds.) Narrative and Identity: Studies in autobiography, Self and Culture. John Benjamins, Philadelphia.

Florian, A. (1994). Treatment of the Holocaust in Romanian textbooks. In R.L.Braham (Ed.), The tragedy of Romanian Jewry. New York: Columbia University Press.

Hobsbawn, E.J. (1972). The social function of the past: Some questions. Past and Present, vol.LV

loanid, R. (2000). The Holocaust in Romania: The Destruction of Jews and Gypsies under the Antonescu regime, 1940-1944. Chicago: Ivan $\mathrm{R}$ Dee.

Mannheim, K. (1952). The problems of generations.

In Essays on the sociology of knowledge (pp. 276-322). London: Routledge \& Kegan Paul.

Rosenberg, T. (1995). The haunted land: Facing Europe's ghosts after Communism. New York: Vintage Books.

Shafir, M. (1994). Anti-Semitism in the postCommunist era. In R.L.Braham (Ed.), The tragedy of Romanian Jewry. New York: Columbia University Press.

Spence, D. (1982). Narrative truth and historical truth: Meaning and interpretation in psychoanalysis. New York: Norton.

Stierlin, H. (1981). The parent's Nazi past and the dialog between generations. Family 
Process, 20 (4), 379-390.

Swedenburg, T. (1995). Memories of revolt.

Minneapolis: University of Minnesota Press.

The Id: Fall 2003 - Vol. 1 